\title{
The Symbolic Element in History
}

\section{Citation}

Darnton, Robert. 1986. The symbolic element in history. Journal of Modern History 58(1): 218-234.

\section{Published Version}

http://dx.doi.org/10.1086/242949

\section{Permanent link}

http://nrs.harvard.edu/urn-3:HUL.InstRepos:3403043

\section{Terms of Use}

This article was downloaded from Harvard University's DASH repository, and is made available under the terms and conditions applicable to Other Posted Material, as set forth at http:// nrs.harvard.edu/urn-3:HUL.InstRepos:dash.current.terms-of-use\#LAA

\section{Share Your Story}

The Harvard community has made this article openly available.

Please share how this access benefits you. Submit a story.

Accessibility 


\title{
Review Article
}

\section{The Symbolic Element in History}

\author{
Robert Darnton \\ Princeton University
}

A funny thing happened to me on my way home from the semiotics seminar. As I rounded a corner on C floor of the library, I noticed an advertisement from the New York Times pasted on the door of a student's carrel: "Fiji $\$ 499$." Primed by a discussion of Charles S. Peirce and the theory of signs, I immediately recognized it as - well, a sign. Its message was clear enough: you could fly to Fiji and back for $\$ 499$. But its meaning was different. It was a joke, aimed at the university public by a student grinding away at a thesis in the middle of winter, and it seemed to say: "I want to get out of this place. Give me some air! Sun! Mehr Licht!" You could add many glosses. But to get the joke, you would have to know that carrels are cells where students work on theses, that theses require long spells of hard labor, and that winter in Princeton closes around the students like a damp shroud. In a word, you would have to know your way around the campus culture, no great feat if you live in the midst of it, but something that distinguishes the inmates of carrels from the civilian population gamboling about in sunshine and fresh air. To us, "Fiji $\$ 499 "$ is funny. To you, it may seem sophomoric. To me, it raised a classic academic question: how do symbols work?

The question had been worrying me in connection with some criticism of a book I had published in 1984, The Great Cat Massacre and Other Episodes of French Cultural History. In the book I had tried to show why a ritual slaughter of cats was hilariously funny to a group of journeymen printers in Paris around 1730. By getting the joke, I had hoped to "get" a key element in artisanal culture and to understand the play of symbols in cultural history in general. My critics raised some questions, which clung to "Fiji \$499" in my thoughts as I trudged home through the dark. I would like to discuss those questions, not as a rebuttal to the criticism, for I still think my argument stands, but as an informal way of wandering through some general problems concerning the historical interpretation of symbols, rituals, and texts.

In a long review of The Great Cat Massacre, Roger Chartier argues that the book is flawed by a faulty notion of symbols. ${ }^{1}$ According to him, symbolism

${ }^{1}$ Roger Chartier, “Text, Symbols, and Frenchness," Journal of Modern History 57 (1985): 682-95. For other observations about the theoretical issues raised in The Great Cat Massacre, see the essays by Philip Benedict and Giovanni Levi published together as "Robert Darnton e il massacro dei gatti," Quaderni Storici, n.s., no. 58 (April 1985), pp. 257-77. I have attempted to answer the criticism in a debate with Pierre Bourdieu and Roger Chartier published as "Dialogue à propos de l'histoire culturelle" in Actes de la recherche en sciences sociales, no. 59 (September 1985), pp. 86-93. 
involves a direct "relation of representation" between the signifier and the signified, as in the example cited in the eighteenth-century dictionary of Antoine Furetière: "The lion is the symbol of valor." I agree that contemporary dictionaries can be useful for tracing meanings attached to words by the literate elite. But I do not think a sophisticated writer like Furetière can serve as a "native informant" about the conception of symbolism among illiterate working people. Nor do I believe that Furetière provides an adequate concept of symbolism for ethnographic analysis.

Ethnographers work with a very different notion of symbolic exchange. Actually, they favor competing notions; but whatever their theoretical stripe, they do not generally expect their native informants to use symbols of the lion = valor variety. Instead, they find that symbols convey multiple meanings and that meaning is construed in different ways by different people. As Michael Herzfeld puts it, "Symbols do not stand for fixed equivalences but for contextually comprehensible analogies." ants, Herzfeld found that symbols signified many things, most of them unexpected and all of them impenetrable to anyone who could not pick his way through the multiple associations attached to crows, crocuses, pebbles, and other objects in the local culture. Several generations of anthropologists have had the same experience. Wherever they go, they find natives construing symbols in complex and surprising ways: thus the harp and rattle among the Fang in Gabon according to James Fernandez, butterflies and carrion beetles among the Apache in Arizona according to Keith Basso, trees and trails among the Ilongot in the Philippines according to Renato Rosaldo, and houses and flowers among the Tamil in southern India according to E. Valentine Daniel. ${ }^{3}$ One could go on and on citing examples, but it might be more useful to take a look at a few case studies.

Loring Danforth applied Herzfeld's concept of symbolism to a study of death rituals in rural Greece. ${ }^{4} \mathrm{He}$ found that funerals worked as a negative transformation of marriage ceremonies and that the symbols used in funeral

${ }^{2}$ Michael Herzfeld, "An Indigenous Theory of Meaning and Its Elicitation in Performative Context," Semiotica 34 (1981): 130; see also pp. 135-39.

${ }^{3}$ James W. Fernandez, "Symbolic Consensus in a Fang Reformative Cult," American Anthropologist 67 (1965): 902-29; Keith Basso, “"Wise Words' of the Western Apache: Metaphor and Semantic Theory," in Meaning in Anthropology, ed. Keith Basso and Henry Selby (Albuquerque, N.M., 1976), pp. 93-122; Renato Rosaldo, Ilongot Headhunting, 1883-1974: A Study in Society and History (Stanford, Calif., 1980); and E. Valentine Daniel, Fluid Signs: Being a Person the Tamil Way (Berkeley and Los Angeles, 1984). For further examples and different varieties of symbolic anthropology, see the following collections of essays: Basso and Selby, Meaning in Anthropology; J. David Sapir and J. Christopher Crocker, eds., The Social Use of Metaphor: Essays on the Anthropology of Rhetoric (Philadelphia, 1977); and Janet L. Dolgin, David S. Kemnitzer, and David M. Schneider, eds., Symbolic Anthropology: A Reader in the Study of Symbols and Meanings (New York, 1977).

${ }^{4}$ Loring M. Danforth, The Death Rituals of Rural Greece (Princeton, N.J., 1982). 
laments helped peasants cope with their grief by metaphorically transforming death into life. Throughout their mourning, women dressed in black gather at the graves of their dead and improvise songs. They often rebuke the dead for causing them pain: "You have poisoned us." The poison takes the form of bitter, burning tears. But tears also water the grave, restoring fertility to the soil and providing the dead with water to drink, cook, and bathe. So in the laments, the dead reply to the despair of the bereaved with affirmative metaphors:

Strangers, kinsmen, and all you who grieve, come near.

Say a few words to me and shed a few tears.

So that the tears become a cool spring, a lake, an ocean, and flood down into the underworld;

so that the unwashed can wash, and the thirsty can drink;

so that good housewives can knead and bake bread;

so that handsome young men can comb and part their hair. ${ }^{5}$

According to Danforth, water has great power as a metaphor in the arid hinterland of Greece. Wetness suggests fertility and life; dryness, barrenness and death. By seeping through the dry earth of graveyards, water is thought to quicken the dead. Widows pour water on the graves of their husbands and describe themselves as burned by their grief: hence the blackness of their dress and the "poison" of their tears. But the tears also flow as water to the dead. They combine the attributes of water and poison and therefore mediate the opposition between life and death. The mediation takes the form of a graduated series of binary opposites, which become progressively weaker until they are fused in the symbol of tears (see fig. 1).

If poetry cannot dissolve death, it can remove its sting, at least for a few moments of suspended disbelief. How does poetry work? Not by setting up mechanical "relations of representation," but by making things flow into each other across the boundaries that divide them in the prosaic world. Historians feel more comfortable in prose. They order things sequentially and argue from effect to cause. But ordinary people in everyday life have to find their way through a forest of symbols. Whether they try to turn a profit, tote a barge, or lift a bale, they manipulate metaphors. That is not to say that economic and power relations have no independent existence but that they are mediated through signs. Money itself is a sign and cannot be made by someone who cannot read the code of his culture. When we face the fundamentals of the human condition, the contradiction between life and death, the mystery of suffering and love, we draw on symbols that give off many meanings. Some may be directly representational-blackness stands for death-but others will drift free from their sensory moorings and will float up against each other, converging in configurations that embody many ideas at once.

${ }^{5}$ Ibid., pp. 110-11. 
Life

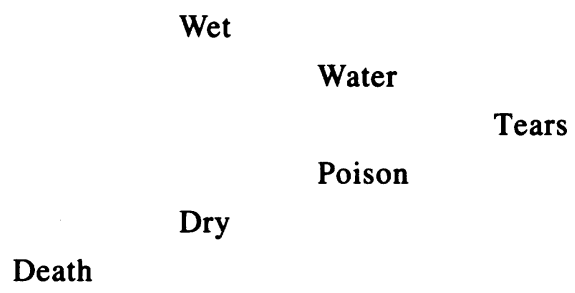

FIG. 1

A few cultural historians have seen metaphorical relations at the heart of what they study. Thus Huizinga on religious experience in the late Middle Ages:

The vision of white and red roses blooming among thorns at once calls up a symbolic assimilation in the medieval mind: for example, that of virgins and martyrs, shining with glory in the midst of their persecutors. The assimilation is produced because the attributes are the same: the beauty, the tenderness, the purity, the colors of the roses, are also those of the virgins, their red color that of the blood of the martyrs. But this similarity will only have a mystic meaning if the middle term connecting the two terms of the symbolic concept expresses an essentiality common to both; in other words, if redness and whiteness are something more than names for a physical difference based on quantity, if they are conceived as essences, as realities. The mind of the savage, of the child, and of the poet never sees them otherwise. ${ }^{6}$

Like Danforth, Huizinga insists that symbolism works as a mode of ontological participation rather than as a relation of representation. Instead of representing the virgins and martyrs, the roses are them, belong with them in the same order of being.

This notion of symbolism, which Huizinga formulated without benefit of linguistic philosophy or semiotics (but with a remarkable knowledge of Sanskrit), has become a dominant theme in current anthropology. It stands out especially in the work of Victor Turner. In many years of fieldwork among the Ndembu, a Zambian people given to elaborate rituals and enthusiastic discussion of them, Turner found symbols everywhere-embodied in the landscape, floating through the air, fixed for an instant in one ceremony and then spilling into another. At the center of this world, brimming over with meaning, stood the mudyi or milk tree. The Ndembu used it to say a thousand things on as many different occasions. After elaborate investigation, confirmed in every detail by native exegetes, Turner concluded that the meanings attached to the tree stretched across a spectrum, ranging from the normative to the sensory:

${ }^{6}$ Johan Huizinga, The Waning of the Middle Ages (Garden City, N.Y., n.d.; original ed. in Dutch, 1919), pp. 203-4. 
The mudyi tree . . . at its normative pole represents womanhood, motherhood, the mother-child bond, a novice undergoing initiation into mature womanhood, a specific matrilineage, the principle of matriliny, the process of learning "woman's wisdom," the unity and perdurance of Ndembu society, and all of the values and virtues inherent in the various relationships - domestic, legal, and politicalcontrolled by matrilineal descent. Each of these aspects of its normative meaning becomes paramount in a specific episode of the puberty ritual; together they form a condensed statement of the structure and communal importance of femaleness in Ndembu culture. At its sensory pole, the same symbol stands for breast milk (the tree exudes milky latex) . . . mother's breasts, and the bodily slenderness and mental pliancy of the novice (a young sapling of mudyi is used). The tree, situated a short distance from the novice's village, becomes the center of a sequence of ritual episodes rich in symbols (words, objects, and actions) that express important cultural themes. ${ }^{?}$

This kind of ethnographic exegesis may seem too good to be true or, at least, to be useful outside the bush. But it should help us sort out symbolic encounters in everyday life. When I ran into "Fiji $\$ 499$," I found to my surprise that the Peircean categories fit. The "sign" consisted of the letters printed as an advertisement. The "object" or ostensible message concerned the fare to Fiji. And the "interpretant" or meaning was the joke: "I want to get out of here." In fact, the meanings multiplied at my end of the communication circuit. "This Peirce stuff really works," I concluded and then added afterthoughts: "We make our students spend too much time in carrels." "Students are getting wittier." Were my interpretations valid? Yes, as far as I was concerned, but did they correspond to what the student had intended? Unable to resist the chance to question a native informant, I knocked at the door of carrel C $1 \mathrm{H} 9$ on the following day. It was opened by Amy Singer, a graduate student in Near Eastern Studies. "I put it up two weeks before generals," she reported. "It was the bleakest moment of the winter, and the New York Times offered this piece of solace, a warm place, far away." But Amy seemed to be a sunny, upbeat type. (I'm happy to report that she did very well in her general examinations.) She said that she thought of the sign more as an escape fantasy and a joke than as a lament. "It's like a bumper sticker," she explained. I had not thought of the door as a bumper. My ideas did not coincide perfectly with hers, but they were close enough for me to get the joke and to feel reinforced in my admiration for Peirce.

Now, I do not want to argue for Peircean as opposed to other systems of semiotics. I want to make a simpler point: we think of the world in the same way as we talk about it, by establishing metaphorical relations. Metaphorical relations involve signs, icons, indices, metonyms, synecdoches, and all the other devices in the rhetorician's bag of tricks. Philosophers and linguists sort the tricks into different definitions and schemata. For my part, I feel

7 Victor W. Turner, “Symbols in African Ritual," Symbolic Anthropology, p. 185. For further discussion and documentation, see Turner, The Forest of Symbols: Aspects of Ndembu Ritual (Ithaca, N.Y., and London, 1967), esp. chaps. 1,3 , and 4 . 
hesitant about subscribing to one system rather than another and prefer to use the term "symbol" broadly, in connection with any act that conveys a meaning, whether by sound, image, or gesture. The distinction between symbolic and nonsymbolic acts may be as fleeting as the difference between a wink and a blink, but it is crucial to understanding communication and interpreting culture. So cultural historians might stand to gain by rejecting the lion-valor view of symbolism and by thinking of symbols as polysemic, fluid, and complex.

But why do certain symbols possess special powers? What makes them unusually rich in meaning? An answer to those questions might begin with Lévi-Strauss's observation that just as some things are good to eat, others are "good to think." People can express thought by manipulating things instead of abstractions - by serving certain slices of meat to certain members of the tribe, by arranging sand in certain patterns on the floor of the hogan, by lying at the foot of the mudyi tree, and by killing cats. Such gestures convey metaphorical relations. They show that one thing has an affinity with another by virtue of its color, or its shape, or their common position in relation to still other things. ${ }^{8}$

Those relations cannot be conceived without reference to a set of categories that serve as a grid for sorting out experience. Language provides us with our most basic grid. In naming things, we slot them into linguistic categories that help us order the world. We say that this thing is a fish and that a fowl, and then we feel satisfied that we know what we are talking about. To name is to know - to fit something in a taxonomic system of classification. But things do not come sorted and labeled in what we label as "nature." And just when we feel confident that we have found a way through the undifferentiated continuum of the natural world, we may stumble upon something startling, like a snake, which produces a brief moment of terror-zero at the bone-by slicing across the categories and spreading static throughout the system. Snakes are neither fish nor fowl. They slither on land as if they were swimming in water. They seem slimy. They cannot be eaten. But they are good for snide remarks: "Stephen is a snake in the grass." Things that slip in between categories, that straddle boundaries, or spill beyond borders threaten our basic sense of order. They undermine its epistemological ground. Such things are powerful and dangerous. They, too, have a name, at least in anthropology: they are taboo.

Anthropologists have encountered taboos in every corner of the world and have discussed them in a vast literature. The most recent round of discussion began with Mary Douglas's observation that dirt was "matter out of place"that is, something that violated conceptual categories. ${ }^{9}$ Thus the prohibition

${ }^{8}$ Claude Lévi-Strauss, The Savage Mind (Chicago, 1966; original ed. in French, 1962), esp. chap. 1.

${ }^{9}$ Mary Douglas, Purity and Danger: An Analysis of the Concepts of Pollution and Taboo (London, 1966), p. 35. The next two paragraphs are based on this book. 
on eating pork among the ancient Israelites had nothing to do with the seemingly "filthy" habits of the pig. It derived from the categorical imperatives of Leviticus, which separated animals into the cud chewing (like cows, nontaboo) and the cloven footed (like goats, also nontaboo). Because they did not chew their cud but did have separated hooves, pigs threatened the purity of the biblical order and had to be abominated. Similar hybrids - shellfish, which have legs like land animals but live in the water, and insects, which have legs like land animals and live in the air-were to be avoided for the same reason. They violated distinctions that began at the Creation, when God separated the earth, the sea, and the firmament. To the Jews, therefore, diet served as a way of worshiping their God and maintaining their cosmology; and pigs, in being bad to eat, were good to think.

Douglas's biblical exegesis might seem too clever to be convincing, but it spoke to a crucial question posed earlier by A. R. Radcliffe-Brown: why do some animals have special ritual value? Lévi-Strauss had pointed the way toward an answer by shifting the discussion from social functions to conceptual categories. Douglas showed that the danger of collapsing categories was linked with the notion of taboo. In her fieldwork in central Africa, she found that the Lele people order the animal world by means of an elaborate taxonomy and that they maintain order by punctilious dietary restrictions. Yet in their most sacred rituals, they consume an animal, the pangolin or scaly anteater, that contradicts their most important categories. The pangolin has scales like a fish, climbs trees like a monkey, lays eggs like a chicken, suckles its young like a pig, and gives birth to single offspring like a human. To ordinary Lele under ordinary circumstances it is hideously monstrous. But in rituals it becomes good to eat and produces fertility. Like other holy substances, it dissolves categories and puts the initiate in contact with an order of being where divisions disappear and everything flows into everything else.

Having caught the scent, anthropologists have tracked strange animals into all sorts of exotic cosmologies. They have bagged enough by now to make a whole menagerie of monsters. I cannot do justice to their findings here, but I would suggest a quick tour, which leads from Douglas's pangolin to Ralph Bulmer's cassowary, Edmund Leach's bitch, and S. J. Tambiah's buffalo. The animals are abominated, isolated in taxonomies, invoked in swearing, avoided in diet, or eaten in rituals by different people in different ways. The anthropologists have shown that those animal folkways make sense because the taboos belong to a system of relations within a general cultural frame.

Bulmer observed that the Karam people of highland New Guinea put the cassowary in a taxonomic class by itself, unlike other highlanders, who classify it as a bird. The Karam also surround it with unusual taboos. While hunting it in the mountain forests above their settlements, they speak "pandanus language," a ritual language of avoidance that they also adopt while gathering nuts from the pandanus palms in the same forest. They dare not shed the cassowary's blood because they fear it will harm the sacred taro crops growing near their homes. So they kill the cassowary with clubs, in hand-to-hand 
combat, as it were. After killing it, they eat its heart and then avoid going near the taro for a month. Bulmer found analogues of these practices in Karam views of kinship, a matrilineal system based on cross-cousins and emblematized in the forest by pandanus palms that belong to particular lines. When kin fight, they must use clubs, not sharp weapons, which they reserve for outsiders. And when one kin kills another, he dispatches its spirit to the forest by eating the heart of a pig. In their main myth about their origins, the Karam relate that a brother trapped his sister, who turned into a cassowary. Outsiders lured her away and ate her. The brother then killed the men and took their sisters as wives, founding the Karam kinship system. When Bulmer's informants told him that they called cassowaries "our sisters and crosscousins," the penny dropped. They thought of the creature as metaphorical cognates, and their way of thinking involved far more than taxonomy. It inhered in the way they ordered the world, a matter of drawing distinctions between kin and outsiders, forest and garden, nature and culture, life and death. ${ }^{10}$

Edmund Leach discovered a similar system of relations within his own backyard. Among the Anglo-Saxon tribes, we, too, have taboos. We feel horrified at the notion of marrying our sister or of eating our dog. We insult one another by saying "bitch" or "son of a bitch." But why not "son of a cow"? What do these dangerous categories - the incestuous, the inedible, the obscene-have in common? Leach, like Douglas, sees them as ambiguous; and like Lévi-Strauss, he attributes their ambiguity to their position as mediators between binary opposites. Pets make particularly good mediators because they straddle opposed spheres, the human and the animal, the domestic and the wild. One can align them with congruent categories in a diagram, which expresses oppositions according to distance from the self (see fig. 2). Just as I cannot marry my sister, I cannot eat my dog; but I can marry my neighbor and eat my cattle. The categories conjugate into each other, and the mediating term carries the taboo. To us, therefore, dogs are not only good for swearing; they are good for thinking. ${ }^{11}$

Tambiah's buffalo occupies a critical position in a set of categories on the other side of the world, in rural Thailand, but it can be thought in a similar way. A Thai identifies with his buffalo just as an Englishman does with his dog. As a child, he guards it in the fields and spends long hours sleeping on its back in the hot sun. As an adult he swears by it-literally, because the words for buffalo and penis are close enough in sound to provide splendid

${ }^{10}$ Ralph Bulmer, "Why Is the Cassowary Not a Bird? A Problem of Zoological Taxonomy among the Karam of the New Guinea Highlands," Man, n.s., no. 2 (1967), pp. 5-25.

${ }^{11}$ Edmund R. Leach, "Anthropological Aspects of Language: Animal Categories and Verbal Abuse," in New Directions in the Study of Language, ed. Eric H. Lenneberg (Cambridge, Mass., 1964), pp. 23-63. I have simplified Leach's diagram and his argument, which extends to a complex set of relations and is not entirely consistent. 


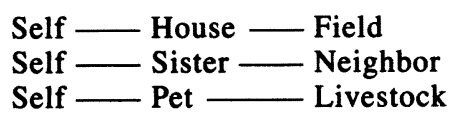

FIG. 2

opportunities for punning. He attributes an ethical existence to his buffalo, for he will not work it, unlike other animals, on the Buddhist sabbath. And he will not eat it. Buffalo make good eating on ritual occasions, but they must come from other households or other villages.

Buffalo fit into Thai households in a peculiar way, for the houses are peculiar places. They are built on stilts according to a strict ordering of space. The sleeping room is located to the north, separated from a guest or reception room by a threshold and divided internally into a western section, allotted to daughters or a married daughter and son-in-law, and an eastern section, reserved for the parents. (Male children sleep with their parents until adolescence, when they move to the guest room.) The father sleeps to the left of his wife at the most eastward section of the sleeping room and at the opposite extreme of the son-in-law sleeping at the far west. The arrangement reinforces sexual taboos, for the son-in-law must never cross over into the eastern section or sleep beside his wife's sisters. And the taboos coincide with spatial values, for the east is considered sacred, auspicious, and masculine in opposition to the impure, inauspicious, and feminine west. A washing place is located on a low level at the extreme western side of the house, and the space under it is considered especially filthy. The buffalo are tethered under the sleeping area. Should one break loose and wallow in the muck under the washing place, it would bring great misfortune upon the house, and a special ritual must be performed to remove the bad luck.

In Thai taxonomy, buffalo coexist with all manner of beasts, some good to eat (the forest rat, which belongs unambiguously to the wilderness), some not (the otter, which slips back and forth between land and water). Tambiah surveys them all, maps the space of the household, and runs through rules of etiquette and marriage. Then he arranges the data in a diagram, which can be read horizontally and vertically for homologies. It shows that the taboos form a congruent series: incest corresponds to a son-in-law crossing over into the parents' sleeping area and to a buffalo wallowing beneath the washing place. The series can be transposed into positive equivalences: recommended marriage corresponds to entertaining kin in the guest room and to feasting on buffalo reared by another household. The spatial, sexual, and dietary rules belong to the same system of relations; and the diagram works as a cultural grid. ${ }^{12}$

Now, structural diagrams in anthropology have a way of looking more like the instructions of a radio kit than the anatomy of a culture. Anthropologists sometimes flounder in formalism. But when the diagrammatic impulse gives

12 S. J. Tambiah, "Animals Are Good to Think and Good to Prohibit," Ethnology 8 (1969): 423-59. 
shape to ethnographic data, they can wed formalism with fieldwork and teach the rest of us a lesson: symbols work not merely because of their metaphorical power but also by virtue of their position within a cultural frame.

These considerations - the polysemic character of symbols, the ritual value of animals, and the cultural frame that makes symbols and animals meaningful-can help one make sense of that strange episode, the ritual massacre of cats by workers in a printing shop in Paris around 1730. I do not want to belabor a subject I have already discussed, but I think it might be useful to look once more at the cat massacre in order to see how anthropological theory can help in the analysis of a historical problem. ${ }^{13}$

The problem begins with difficulties of documentation. We can only know the massacre from an account written many years later by one of the men who organized it, Nicolas Contat. Although we can trace Contat to an actual printing shop and can confirm many of the details in his narrative, we cannot be sure that everything happened exactly as he said it did. On the contrary, we must allow for stylized elements in his text. It belongs to a genre of working-class autobiography made famous by two of his contemporaries from the printing trade, Benjamin Franklin and Nicolas Edmé Restif de la Bretonne. And it includes elements from two other genres: the misère, or burlesque lament about the hard life of workers in certain trades, and the technical manual, a variety of "how-to" literature popular among printers. Because Contat shaped his text according to generic constraints, we cannot treat it as if it were a window, which provides an undistorted view of his experience. ${ }^{14}$

But after generations of struggle to discover "what actually happened," historians have learned to cope with documentary problems. And if they want to understand what a happening actually meant, they can take advantage of the very elements that may distort a text as reportage. By situating his narrative in a standard way, drawing on conventional images, and blending stock associations, a writer puts across a meaning without making it explicit. $\mathrm{He}$ builds significance into his story by the way he recounts it. And the more ordinary his manner, the less idiosyncratic his message. If he adopts an

${ }^{13}$ For an analysis of the massacre and references to the ethnographic data used to interpret it, see Robert Darnton, The Great Cat Massacre and Other Episodes in French Cultural History (New York, 1984), chap. 2. The episode itself is recounted in Nicolas Contat, Anecdotes typographiques, où l'on voit la description des coutumes, moeurs et usages singuliers des compagnons imprimeurs, ed. Giles Barber (Oxford, 1980), pp. 48-54. All quotations in the following paragraphs come from that source.

${ }^{14}$ As an example of a misère, see "La Misère des Apprentifs Imprimeurs," printed by Giles Barber at the end of his edition of Contat's Anecdotes typographiques, pp. 101-10. The manuals contain a great deal of information about the folkways as well as the technology of printing, and they go back to the sixteenth century. Two manuals that have much in common with Contat's text, although they come from a slightly later period, are S. Boulard, Le manuel de l' imprimeur (Paris, 1791); and A.-F. Momoro, Traité élémentaire de l'imprimerie ou le manuel de l'imprimeur (Paris, 1793). 
excessively sibylline style, he will not be understood; for understanding depends on a common system of meaning, and meanings are shared socially. Therefore we can read a text like Contat's not to nail down all the whos, whats, wheres, and whens of an event but rather to see what the event meant to the people who participated in it. Having worked out a tentative interpretation, we can go to other documents - contemporary collections of proverbs, folklore, autobiographies, printing manuals, and misères - to test it. By moving back and forth between the narrative and the surrounding documentation, we should be able to delineate the social dimension of meaning - to "get" the cat massacre just as we can get "Fiji \$499."

Without wading through all the material once again, I think it important to point out that Contat's account of the massacre takes as its starting point the misères of the two apprentices, Jérôme (the fictional counterpart of Contat) and Léveillé. The master overworks them, sleeps them in a cold and clammy lean-to in the courtyard of the shop, and feeds them on such rancid, rotten meat that even the house cats will not touch it. As in most misères, the tone is humorous rather than angry. Apprentices were supposed to be the butt of jokes and ill treatment, a kind of hazing considered appropriate to their position between childhood and adulthood. Contat fills his story with descriptions of the initiation rites that marked off the apprentices' arrival in the shop and their final integration into the world of the journeymen. Like other liminal characters, they test the boundaries of adult norms by playing tricks and getting into trouble. When they bamboozle the master into inadvertently ordering the slaughter of his wife's favorite pet cat, la grise, the incident has all the ingredients of a standard farce.

But Contat's way of telling the joke sets it in the context of a deeper animosity between the workers and the master. At the beginning of his narrative, he invokes a mythical past, when printing shops were true "republics" where masters and journeymen lived together as equals, sharing the same food and work. In the recent past, however, the masters, or bourgeois as they were called, had excluded the journeymen from masterships and had driven down their wages by hiring semiskilled workmen (alloués). Documents from the archives of the Parisian booksellers' guild confirm that the position of the journeymen did indeed deteriorate during the late seventeenth and early eighteenth centuries. But Contat goes beyond the question of wages to the development of incompatible subcultures. He shows at many points that the journeymen did all the work while the master slept late, dined extravagantly, adopted airs of affected gentility and bigoted piety, and generally withdrew into an alien, bourgeois way of life.

Cats epitomized this parting of the folkways. To the bourgeois they were pets. In fact, Contat claimed that a rage for keeping cats had spread among the masters of the printing shops. One master had twenty-five of them. He gave them the finest morsels from his table and even had their portraits painted. Workers did not think of animals as pets. To them, domestic cats were like alley cats - good for bashing on festive occasions like the feast of Saint John, when they were burned by the sackful, or during charivaris, when 
they were torn limb from limb ("faire le chat" it was called in Dijon). Cats also had a satanic quality. They went about at night as familiars of witches and copulated hideously during nighttime witches' sabbaths. A standard defense if one crossed you was to maim it with a club. On the following day, a suspicious old hag would be seen with a broken limb or covered with bruises. Many superstitious practices and proverbs linked cats with households, especially with the mistress of the house and specifically with the genitals of the mistress. Pussy (le chat and particularly the feminine la chatte) meant the same thing in the slang of eighteenth-century France as it does in colloquial English today. A girl who got pregnant had "let the cat go to the cheese." And men who liked cats had a special way with women: "As he loves his cat, he loves his wife."

Contat evokes these commonplaces of French folklore throughout his narrative. He makes the connection with sorcery explicit, links care for la grise with "respect for the house," and suggests a sexual element in the identification of the mistress with her cat. She appears as a lusty wench who combines a "passion for cats" with a penchant for cuckolding her husband. After the apprentices have killed la grise, Contat notes what the "murder" meant to husband and wife: "To her they had ravished a cat [chatte] without a peer, whom she loved to the point of madness; and to him, they had attempted to sully his reputation." The whole episode demonstrated that cats were extremely good to think.

It also showed that they had great ritual value, for the massacre followed a scenario that combined a whole series of rituals. It began as a typical prank, which the apprentices devised in response to a typical misère: sleeplessness. They have to get up at the crack of dawn in order to open the gate for the first journeymen who arrive for work. And they have great difficulty falling asleep at night, because a collection of alley cats has taken to wailing near their miserable bedroom. The bourgeois, who gives himself over to grasses matinées as much as to haute cuisine, sleeps through it all. So the boys decide to turn the tables on him. Léveillé, a "perfect actor" who can imitate anything, scampers across the roof "like a cat" and caterwauls outside the master's window so raucously that the old man cannot sleep any more.

The master is as superstitious in religion as he is despotic in the running of the shop. He decides that some witches have cast a spell and commissions the boys to get rid of the "malevolent animals." After arming themselves with bars from the presses and other tools of their trade, Jérôme and Léveillé lead the workers on a gleeful cat hunt. The mistress has warned them not to frighten la grise, so they dispatch it first and stuff its body in a gutter. Then the entire work force sets to, smashing through the cat population of the whole neighborhood and piling up the half-dead bodies in the courtyard of the printing shop. The workers name guards, a judge, a confessor, and an executioner, and proceed to try and condemn their victims. Then they hang them, roaring with laughter. The mistress comes running and lets out a shriek, as she thinks she sees la grise dangling from a noose. The workers assure her they would not do such a thing: "They have too much respect for the 
house. The bourgeois arrives. 'Ah! The scoundrels,' he says, 'Instead of working they are killing cats.' Madame to Monsieur: 'These wicked men can't kill the masters, so they have killed my pussy." "As the workers guffaw, the master and mistress withdraw in humiliation, he muttering about the time lost from work, she lamenting her lost chatte. "It seems to her that all the blood of the workers would not be sufficient to redeem the insult."

In the succeeding weeks, Léveillé repeats the farce over and over again by staging pantomimes, known as "copies," in the shop. He can improvise numbers as skillfully as the vaudevillians in the street theaters of the Foire Saint Germain a few blocks away. The journeymen applaud in their traditional manner, by beating their tools and bleating like goats. They aim this rough music, standard fare in charivaris, at the bourgeois. For he is the butt of the joke. They have got his goat. Again and again he falls victim to a kind of shop vaudeville called joberie in the workers' slang. He is repeatedly tried and condemned in a mock trial like the burlesque court scenes that the workers stage on the feast of Saint Martin, when they square accounts for infringements of their shop code. The whole procedure takes place in a spirit of carnival revelry. As at Mardi Gras, when young men make rough music in mockery of cuckolds, the apprentices take charge: "Monsieur Léveillé and Jérôme, his comrade, preside over the fête." And they double the hilarity by transforming the carnival into a witch hunt. The maiming of the cats passes as a standard defense against sorcery. But the boys have faked the witching in the first place; so they can exploit the master's credulity in order to insult his wife. By bludgeoning her familiar, they accuse her of being a witch and then compound the insult by playing on the sexual associations of pussy-a case of metonymic rape, the symbolic equivalent of murder, even though she cannot accuse them of anything more than horseplay because they have disguised their meaning in metaphor.

Of course the metaphor also drove their meaning home, and it conveyed different messages to different persons. Contat recounts the massacre from the viewpoint of the workers, so it appears primarily as a humiliation of the bourgeois. To them, nothing could be more insulting for the boss than an attack on his most prized possession, his wife's chatte. The wife's reaction suggests she recognized that the aggression carried over from her cat to her person and her husband. Hence her remark, which otherwise would be a non sequitur: "These wicked men can't kill the masters, so they have killed my pussy [ma chatte]." But the master was too obtuse to realize how badly he had been had and merely raged at the loss of work caused by the buffoonery.

Although the humor may not survive too much analysis, I think it valid to conclude that the joke worked because the boys were able to play so many variations on standard cultural themes. They staged a virtuoso performance: polysemic symbolism compounded by polymorphic ritualism. The symbols reverberated up and down a chain of associations - from the cats to the mistress, the master, and the whole system of law and social order parodied by the trial. The rituals fit into one another, so that the workers could move back and forth among four basic patterns. They turned a roundup of cats into 
a witch hunt, a carnivalesque festival, a trial, and a bawdy variety of street theater. True, they did not execute any one of the rituals in complete detail. To do so would have excluded the possibility of invoking the others. Had they burned the cats instead of hanging them, they would have stayed closer to the festival tradition of Mardi Gras and the feast of Saint John, but they would have sacrificed the ceremonial legalism attached to criminal trials and the feast of Saint Martin. Had they abandoned their rough music, they would have created a more authentic court atmosphere, but they would have failed to express the idea of getting the master's goat (making him "prendre la chèvre") and of turning the shop into a theater. In short, they played with ceremonies just as they did with symbols, and to understand their legerdemain we should avoid heavy-handedness and literal-mindedness in our own attempts to make sense of their joking. If we insist on finding a complete and unabridged charivari or witch trial in Contat's text, we will miss the point. For Contat showed that the workers quoted bits and pieces of rituals, just enough to get their message across and to exploit the full range of meanings by associating one traditional form with another. The massacre was funny because it turned into a game of ritual punning. ${ }^{15}$

Now, this kind of open-ended interpretation may make the reader uneasy. Historians like to nail things down, not pry them loose. It goes against the professional grain to argue that symbols can mean many things at the same time, that they can simultaneously hide and reveal their meanings, that rituals can be conjugated into one another, and that workers can quote them, playing with gestures as poets play with words. Doesn't this raise the danger of overinterpretation? Of making unwashed artisans into intellectuals? By way of an answer, I should point out that I do not mean to imply that all the workers extracted all the meaning from the incident. Some of them probably enjoyed the cat bashing and left it at that, while others read all sorts of significance into it. I think the massacre of the cats was like a performance of a play: it could be construed in different ways by different persons, players and spectators alike. But it could not mean anything and everything, just as The Wizard of $O z$ cannot communicate the whole gamut of ideas and emotions in King Lear. For all their multivocality, rituals contain built-in constraints. They draw on fixed patterns of behavior and an established range of meanings. The historian can explore that range and map it with some precision, even if he cannot know precisely how everyone made use of it.

But how can he compensate for the imperfections in the evidence? I cannot take Contat's text as proof that the master's wife actually said, "These wicked men can't kill the masters." Those words represent nothing more than Contat's version of her response to the massacre, long after the fact. But the exact phrasing does not matter so much as the associations it evokes. Contat's narrative may be inaccurate in detail, but it draws on conventional notions,

${ }^{15}$ In this respect, the joke illustrates the notion of switching frames and venting aggression developed by Arthur Koestler. See the essay on "Wit and Humor" in his Janus: A Summing Up (New York, 1978). 


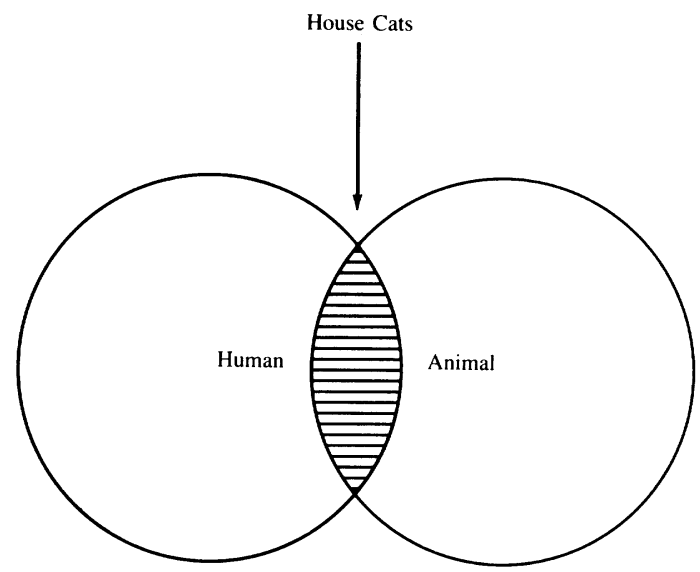

FIG. 3

which connect cats with sorcery, domesticity, and sexuality and which can be confirmed from a variety of other sources. Those connections belong to a system of relations or, if the term may still be used, a structure. Structure frames stories and remains constant, while the details vary in every telling, exactly as in narrations of folk tales and performances of rituals among Greek peasants, African bushmen, Thai villagers, and New Guinea highlanders. ${ }^{16}$

I think one can put the argument formally without subscribing to an elaborate and perhaps outdated variety of structuralism. The story concerns a set of oppositions - between humans and animals, masters and workers, domestic life and wild life, culture and nature. In this schema, the apprentices and house cats are mediating terms. The apprentices operate on the boundary between the shop and the outside world. As gate tenders, they let the workers in from the street; and as errand boys, they scramble around the city during the day but sleep in the house at night. They are treated as children in some respects and as workers in others, for they are liminal creatures, passing between childhood and adulthood. The pet cats also belong in part to the outside world, the sphere of alley cats and animality, yet they live inside the house and are treated more humanely than the boys. As a betwixt-and-between creature of special importance and the favorite of her mistress, la grise is especially taboo. The mistress warns the boys to keep away from her, and Contat describes her killing as a "murder." She occupies an ambiguous space like that of many ritually powerful animals on many ethnographic diagrams (see fig. 3).

The apprentices occupy the same space. In fact, it is disputed territory, for the story begins with the rivalry between the boys and the cats. They compete for food (the boys get cat food, the cats get human food) and also for a position close to the master and mistress within the household. If abstracted from the narrative and spread out diagrammatically, the positions would look

${ }^{16}$ See Vladimir Propp, The Morphology of the Folktale (Austin, Tex., 1968); and Albert B. Lord, The Singer of Tales (Cambridge, Mass., 1960). 


\begin{tabular}{|c|c|c|c|c|c|}
\hline Master-Mistres & Apprentices & & Pet cats & & Alley cats \\
\hline human & human & + & animal & - & animal \\
\hline human food & animal food & - & human food & + & animal food \\
\hline
\end{tabular}

FIG. 4

like those in figure 4. Actually, the cats have displaced the boys in the privileged position next to the master and mistress. In the old "republic" of printing, the apprentices would have shared the master's table. But now they are shunted off to the kitchen, while the pet cats enjoy free access to the dining room. This inversion of commensality was the injustice that set the stage for the massacre. By hanging the cats (a human punishment applied to animals), the boys reversed the situation and restored order in the liminal zone, where the danger of confusing categories was greatest.

The little domestic drama took on great symbolic weight because it became linked with the serious matter of labor relations, which the workers also expressed in a symbolic idiom. In a glossary appended to his story, Contat noted usages that can be confirmed in many printers' manuals. The workers applied animal terms to themselves: pressmen were "bears" and compositors "monkeys." When they made rough music, they bleated like goats. And when they fought, they reared back, let out defiant "baas" (bais) and grappled like goats (to fall into a fury was to "prendre la chèvre"). The workers belonged to the untamed world of the street, the world inhabited by the alley cats, who represented animals at their rawest, a caterwauling, copulating animality, which stands in the story as the antithesis to the domestic order of the bourgeois household. So the drama set in motion a system of relations that can be reduced to a final diagram (see fig. 5).

Domestic

(Household)

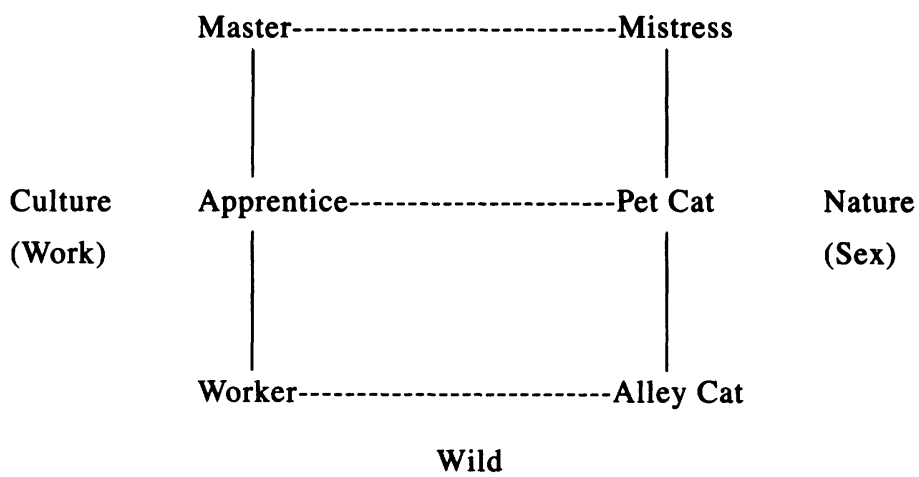

(Street Life)

FIG. 5 
Read horizontally, the diagram depicts relations of identity; read vertically, relations of opposition. The apprentices and pets still operate as mediating terms, but they occupy a larger field of contrasting categories: the domestic or household world versus the world of wildness and street life, the sphere of culture and work versus the sphere of nature and sex. The corners of the diagram define positions where the dimensions are joined. The master stands at the juncture of work and domesticity, the mistress at that of domesticity and sexuality, the alley cats at that of sex and wildness, and the workers at that of wildness and work. Owing to the danger of open insubordination, the workers channeled their aggression through the most roundabout route: they attacked the mistress through the cats and the master through the mistress. But in doing so, they mobilized all the elements of their world. They did not merely tweak the boss's nose. They staged a general uprising-of workers against masters and of the whole sphere of untrammeled, violent, libidinal nature against the disciplined order of work, culture, and domesticity.

I realize that diagrams look mechanical. They seem to strip humanity down to a skeleton. But they can reveal structure; and if we want flesh and blood, we can turn back to the story or try to imagine the massacre as it actually occurred, with all its fur and gore, screaming and laughter. In that case, however, we have nothing more than our imaginations and Contat's narrative to fall back on. In order to sustain a rigorous interpretation, we must attempt to work through the details to the cultural frame that gave them meaning, combining formal analysis with ethnographic material. If my attempt has failed, I hope at least that it may open the way to something more successful. And if all this chasing after symbols has led into a blind alley, the ethnographic historian may console himself with the thought of escape to greener pastures of fieldwork: “Fiji \$499." 